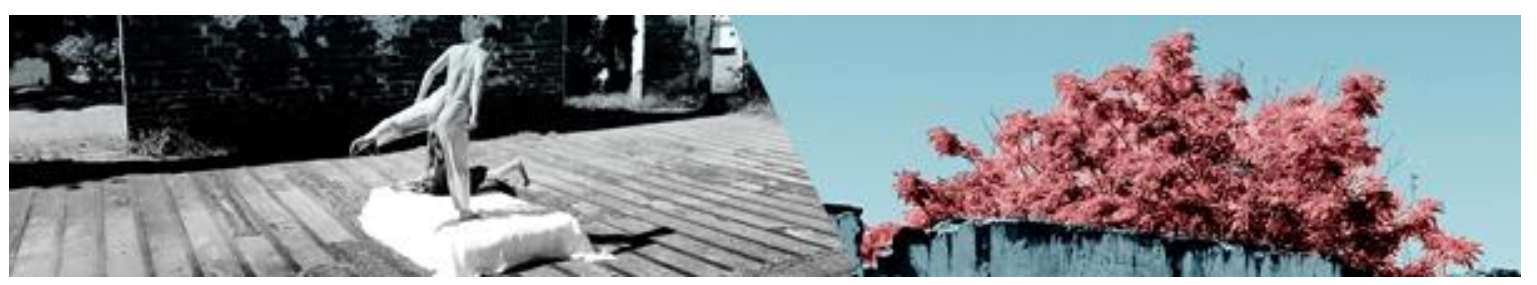

\title{
PROFISSÃO PROFESSOR DE BALÉ: REVISANDO REFERÊNCIAS E CONCEITOS
}

Rebeca Pereira San Martins 1

Eleonora Campos da Motta Santos 2

Resumo: A partir do surgimento das danças de corte na história da arte ocidental, apresentamos uma revisão inicial sobre características e concepções acerca da figura de mestres balé/dança. Fontes históricas acessadas apontam que 0 ato de ensinar dança começa a especializar-se, na Europa, ainda na Idade Média, delineando características para o que hoje compreendemos por professor de balé/dança. $O$ estudo apontou que muitas das práticas e pensamentos em torno da figura do professor, destacadas e até mesmo criticadas pelo francês Jean-Georges Noverre em suas Cartas sobre a Dança (1760), ainda estão presentes e reverberam, hoje, nas atuações dos professores de balé e no imaginário em torno deste universo.

Palavras-chave: Professor de Balé; Revisão; Referências e conceitos.

\section{BALLET TEACHER CAREER: A REVIEW OF REFERENCES AND CONCEPTS}

\begin{abstract}
From the emergence of the court dances in the history of western art, we present an initial review on the characteristics and conceptions about the figure of the ballet/dance masters. Historical sources point out that the act of teaching dance begins to specialize, in Europe, even in the Middle Ages, outlining the characteristics for what we nowadays understand as a ballet/dance teacher. The study showed that many of the practices and thoughts around the teacher's figure, highlighted and even criticized by Jean-Georges Noverre in its Letters on Dance and Ballets (1760), are still present and reverberate today in the performances of ballet teachers and in the imagery around this universe.
\end{abstract} Keywords: Ballet teacher; Review; References and concepts.

\section{Introdução}

Este texto é recorte de Trabalho de Conclusão no Curso de DançaLicenciatura da Universidade Federal de Pelotas, cujo estudo envolveu o desejo de compreender a narrativa de professoras de dança, mais especificamente de professoras de balé clássico. Tendo em vista a temática, julgamos importante adentrar no universo conceitual acerca da figura do professor de balé para buscar

1 Graduanda do curso de Dança Licenciatura da Universidade Federal de Pelotas, estagiária na Escola de Belas Artes Heitor de Lemos e professora no Espaço de Dança Raquel Pereira e Sociedade Amigos do Cassino.

2 Professora Doutora, do Curso de Dança Licenciatura do Curso do Centro de Artes da Universidade Federal de Pelotas.

MARTINS, Rebeca Pereira San; SANTOS, Eleonora Campos da Motta. Profissão professor de balé: revisando referências e conceitos. Revista da FUNDARTE, Montenegro, p.202-220, ano 19, ํo 37, Janeiro/Março.

Disponível em: http://.seer.fundarte.rs.gov.br/index.php/RevistadaFundarte/index> 30 de março de 2019. 


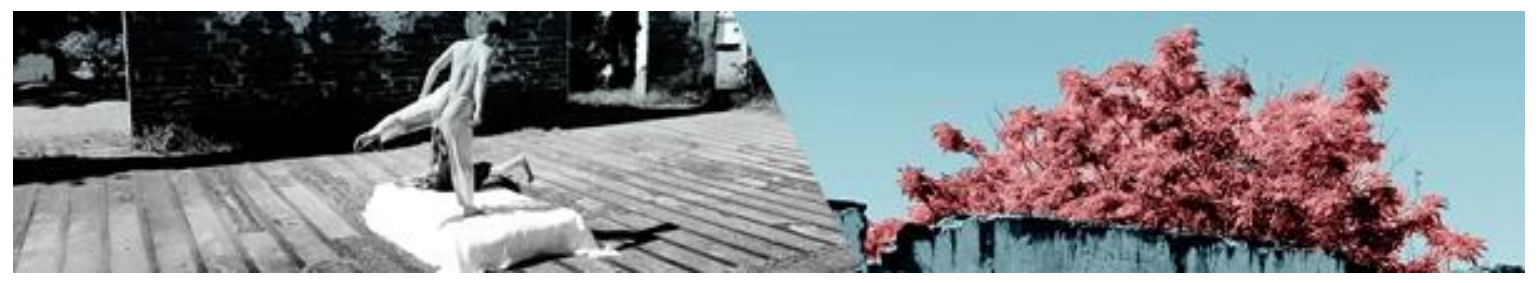

compreender como imagens desta profissão foram se cristalizando ao longo da história da dança no ocidente.

Neste sentido, este trabalho procura esboçar os caminhos dos mestres de dança no ocidente, que surgiram na época das danças de corte, período no qual as referências históricas acessadas apontam que o ato de ensinar dança começa a se especializar, delineando características para o que hoje compreendemos por professor de dança/balé.

Ao longo do texto, adentramos em aspectos mais específicos sobre a atuação docente, partindo de conceitos trazidos por Jean-Georges Noverre (1727-1810) e suas idealizações em relação ao mestre de balé. Além disso, trazermos reflexão sobre o fazer docente a partir de ideias de autores mais atuais, tanto do âmbito específico da dança como da área da educação.

\section{A profissão professor de dança/balé: apontamentos históricos}

A dança, ao longo da civilização ocidental, sempre esteve muito ligada ao aspecto da cultura e da rotina social de diferentes grupos, estando presente nos ritos de celebração, de morte, fertilização, entre outros momentos importantes considerados pelos povos (BOURCIER, 2006), e sendo realizada, predominantemente, a partir da espontaneidade de movimentos. Importante situar que a referida especialização no ensino da dança, segundo as fontes consultadas, é estabelecida na sociedade europeia da Idade Média, nos contextos sob os quais vivia a classe nobre.

De acordo com Bourcier (2006 apud SANTOS, 2008), na Idade Média, com o poder político e econômico concentrado nas mãos dos reis e da lgreja, as manifestações de dança precisaram voltar sua ênfase ao sentido religioso para continuarem sendo aceitas pelo poder dominante, abrindo mão da espontaneidade.

Assim, segundo o autor, é possível perceber um período de normatização da dança no qual há clara dicotomização entre dança erudita e dança popular: "Cabe à

MARTINS, Rebeca Pereira San; SANTOS, Eleonora Campos da Motta. Profissão professor de balé: revisando referências e conceitos. Revista da FUNDARTE, Montenegro, p.202-220, ano 19, nํ 37, Janeiro/Março.

Disponível em: http://.seer.fundarte.rs.gov.br/index.php/RevistadaFundarte/index> 30 de março de 2019. 


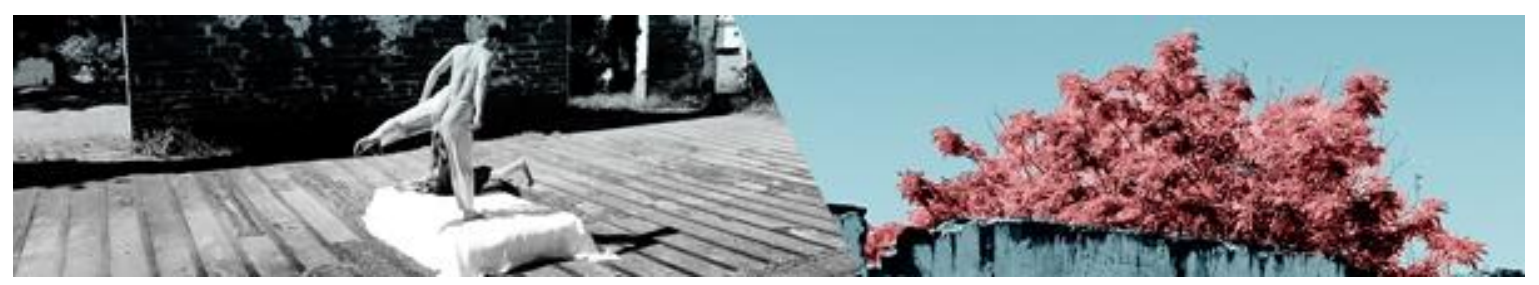

dança popular manifestar sentimentos confusos, fortes - a alegria, a inquietude - e manter ritos, cujo sentido original foi perdido, através de movimentos não sujeitos a regras" (BOURCIER, 2006, p. 54), sendo que, para ser considerado erudito, o que era dançado precisava respeitar um extremo refinamento de forma, tornando-se metrificado para, assim, comungar com pensamento retórico emergente, que perduraria nos séculos seguintes:

[...] Ao contrário, no contexto fixo da música e da poesia, as danças 'metrificadas' serão exercício que exige, antes de mais nada, a beleza das formas; serão as danças das classes desenvolvidas culturalmente, das classes dominantes. (BOURCIER, 2006, p. 54).

Esta busca pelo refinamento de forma na dança, como indica a citação, segue o que, no período, já acontecia com a música e a poesia. De acordo com Bourcier (2006)

A música participa do movimento de busca intelectual. [...] Vão nascer duas correntes, a canção popular e a arte dos trovadores. Os poetas e músicos fecham-se de bom grado em formas fixas e relativamente complicadas [...]. Uma pesquisa paralela de equilíbrio e refinamento marca a dança. A dança "metrificada" é então reinventada, de acordo com a métrica da música ou da poesia que lhe serve de apoio [...]. (BOURCIER, 2006, p. 53).

O propósito é de exaltar o refinamento intelectual dos nobres e, assim, estabelecer distinções cada vez mais evidentes das classes de trabalhadores vassalos. Nas palavras do autor,

[...] o conhecimento, mesmo elementar, das regras simples que regem os movimentos do corpo, assim como uma educação do ouvido, torna-se necessário ao dançarino, eis que nasce a dança erudita. Ao mesmo tempo, esta se separa da dança popular. (BOURCIER, 2006, p. 53-54).

Neste contexto, a metrificação dos movimentos de dança apareceu como uma estratégia para que ela pudesse ser reproduzida de uma forma comum, constituindose como marca de comportamento e atitude de uma classe específica: a nobreza. Por este fato, passou a exigir aprendizado e treino.

É neste momento que, de acordo com as fontes consultadas, se esboça a referência de profissionalização para o ensino de dança, com a aparição dos MARTINS, Rebeca Pereira San; SANTOS, Eleonora Campos da Motta. Profissão professor de balé: revisando referências e conceitos. Revista da FUNDARTE, Montenegro, p.202-220, ano 19, ํㅡㄴ Janeiro/Março.

Disponível em: http://.seer.fundarte.rs.gov.br/index.php/RevistadaFundarte/index> 30 de março de 2019. 


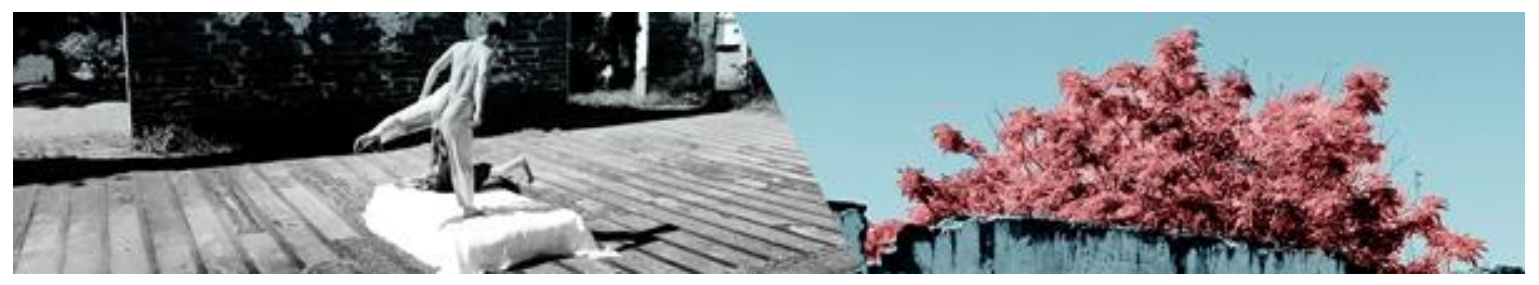

primeiros mestres nessa arte (BOURCIER, 2001). Como já mencionado, muitas das expressões de danças, até esse tempo, não se preocupavam com um padrão metrificado de movimentações. A partir desse novo contexto que se instaura, e com a artificialização das danças nas cortes, há um favorecimento para o surgimento de profissionais que ensinam esses movimentos. A utilização de regras para realizar a definição de movimentos promove, de certo modo, uma tomada de consciência das possibilidades estéticas do corpo. Contudo, não promove a percepção ou intenção de realizar o movimento que se busca e se explora. É a execução da sua forma codificada que tem mais valor.

Os primeiros mestres de que se têm notícias foram pessoas inseridas na corte ou que faziam parte da família dos nobres e, por isso, começaram a realizar essa organização de passos a serem dançados (BOURCIER, 2006). Esses mestres baseavam-se nas manifestações populares de movimentos de dança, estabelecendo neles formas fixas e padronizadas de realização, características que favoreciam a reprodução pelos membros da corte nobre em ascensão.

Por este motivo, como nos aponta Bourcier (2001), começa a haver uma preocupação maior com a forma do movimento do que com a intenção dele: é o início de um caminho para a codificação de movimentos e, como consequência, de uma busca pelo profissionalismo e pelo crescimento do nível técnico de execução da dança entre os nobres (BOURCIER, 2001).

Antes de seguir falando sobre o surgimento desses mestres de dança e de como se desdobrou sua atuação na corte, falaremos brevemente sobre a influência italiana na corte francesa, uma vez que, como apontar-se-á mais adiante, é na corte italiana que as fontes indicam o surgimento das primeiras figuras de mestres de dança. Boucier (2001 apud NUNES 2006) diz que a renascença francesa sempre se espelhou na renascença italiana no que diz respeito à forma de pensar e até mesmo nas artes. Nunes relata que acontecia uma troca muito significativa entre França e Itália onde: ou diplomatas, enquanto os italianos viajavam à França em busca de

MARTINS, Rebeca Pereira San; SANTOS, Eleonora Campos da Motta. Profissão professor de balé: revisando referências e conceitos. Revista da FUNDARTE, Montenegro, p.202-220, ano 19, no 37, Janeiro/Março.

Disponível em: http://.seer.fundarte.rs.gov.br/index.php/RevistadaFundarte/index> 30 de março de 2019. 


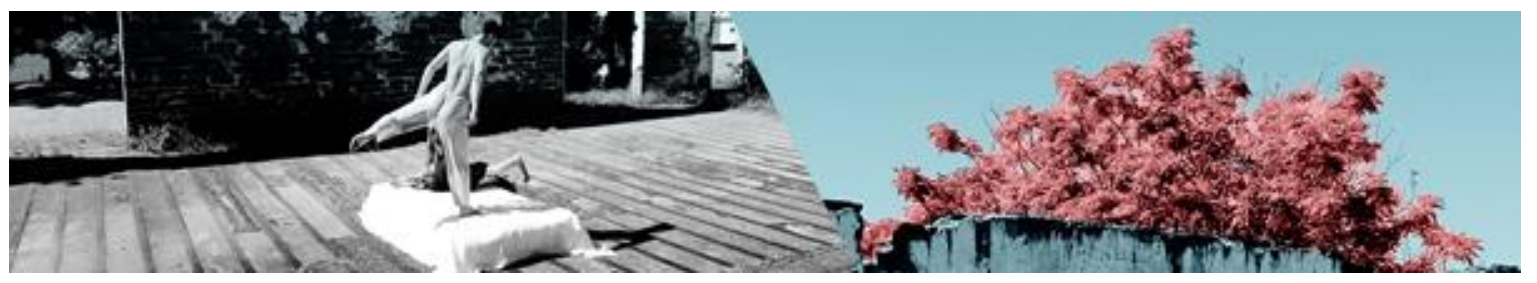

proteção, negócios ou mesmo procurando um lugar nas cortes de reis e rainhas [...]. (NUNES, 2006, p. 34).

O autor, ainda, menciona que inúmeros artistas pertencentes à corte italiana se deslocaram para França, pois estavam inseridos nas comitivas reais como maîtres de dança e instrumentistas (BOURCIER apud NUNES, 2006). Com isso, vários artistas italianos começaram a migrar para a França e os próprios franceses contribuíam para a realização deste deslocamento.

Segundo Nunes (2006) começou a ser percebida a consolidação do interesse da França pela dança italiana a partir do momento que Luís XII, ao retornar para França, levou consigo uma cópia de um dos tratados de dança da Itália; e, também, quando Francisco I deu bastante apreço à dança quando esteve em Milão, cidade italiana. O mesmo autor diz que além dos Maîtres de danse e músicos que vieram da Itália, alguns gêneros de dança também foram importados da Itália para a França. Neste sentido foi possível perceber o quanto a Itália esteve presente na constituição da corte e da dança francesa.

Não podemos deixar de mencionar que foi na ltália onde se deu a constituição dos primeiros tratados de dança, os quais são julgados de extrema importância. Havia grandes mestres na Itália, os quais tiveram um papel importante no momento que fizeram a edição de suas obras voltada para o ensino de dança (NUNES, 2006). Nunes (2006) ainda menciona que estes primeiros maîtres de dança italianos tinham uma vida financeira bastante frágil e que só vieram a ser bem remunerados no momento em que se espalharam pela Europa. É possível que este seja um outro motivo importante para que inúmeros mestres começassem a se deslocar para a França para darem continuidade em seu trabalho na corte francesa.

O primeiro professor de dança que se tem registro foi o mestre Domenico da Piacenza, mestre de dança renascentista italiano, que escreveu um manuscrito denominado o "Primeiro tratado de dança: De arte saltendi et choreas ducendi" (BOURCIER, 2001, p. 65). Piacenza, além de ter coreografado e dirigido inúmeros balés, também atuou como bailarino. De acordo com Nunes (2006), em suas obras

MARTINS, Rebeca Pereira San; SANTOS, Eleonora Campos da Motta. Profissão professor de balé: revisando referências e conceitos. Revista da FUNDARTE, Montenegro, p.202-220, ano 19, ํo 37, Janeiro/Março.

Disponível em: http://.seer.fundarte.rs.gov.br/index.php/RevistadaFundarte/index> 30 de março de 2019. 


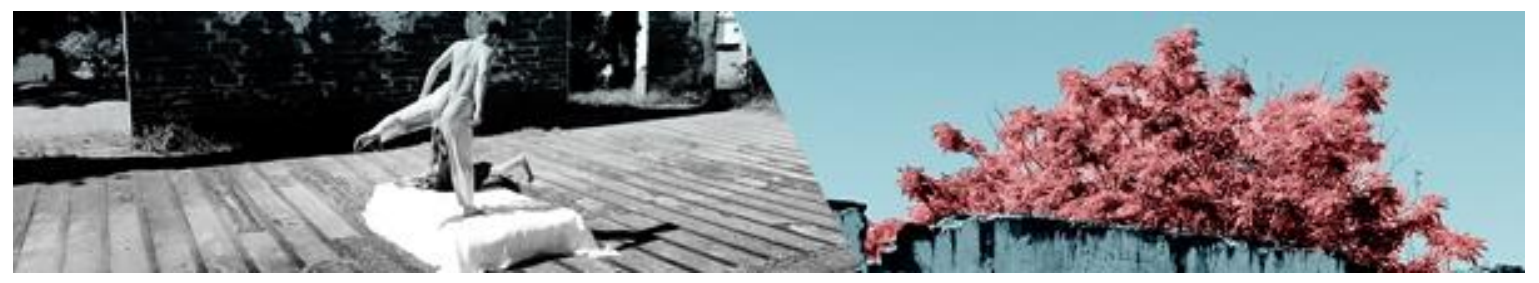

ele prezava pela realização de uma movimentação suave e um equilíbrio corporal, onde desprezava qualquer movimentação ríspida. A evolução dessa dança, que Piacenza traz em seu manuscrito, se desenvolve no próximo século (XVI) e caminha em direção a uma técnica mais rigorosa.

O autor Bourcier (2001, p. 68) relata que Negri, dançarino e mestre italiano que passou grande parte da sua carreira atuando intensamente como violista na corte francesa, teve uma grande atuação na mesma. Sendo ele o primeiro a indicar os chamados piedi in fuore, o qual teria dado início ao uso do en dehors (posição dos membros inferiores rotados para fora). Negri foi um dos mais bem sucedidos e notáveis mestres de dança, sendo que seus escritos são considerados fonte pedagógica de grande importância (NUNES, 2006).

Já sobre Marco Caroso, Bourcier (2001) relata que se intitulava mestre, teórico e compositor e que apresentou, em Veneza em 1591, uma nomenclatura de passos, os quais eram intitulados como cabriola, fioro, salto tondo, pirlotto e o groppo. É possível percebermos que Caroso, talvez, seja um dos grandes incentivadores que sustentou esse primeiro processo de artificialização da dança; sendo, com isto, visto como aquele que possuía uma capacidade maior de ensinar esse novo modelo de dança codificada que começava a surgir, ou seja, momento em que a figura do professor de dança parece ter começado a se constituir de uma maneira mais formalizada.

$\mathrm{Na}$ metade do século XVI, na França, o poder passa a ser exercido pela italiana Catarina de Medici, que desempenha o papel de rainha da França. Ela é referida como quem introduziu o balé na França antes mesmo do seu desenvolvimento teatral (NUNES, 2016). Isto se deu pelo fato de Catarina ter favorecido a vinda de diversos Italianos à corte Francesa, dentre eles aqueles conhecedores das danças que já estavam sendo desenvolvidas nas cortes italianas renascentistas.

Bourcier (2001) informa que, neste período na França, a dança começa a se mostrar bastante presente na corte, onde era possível encontrar um amplo repertório

MARTINS, Rebeca Pereira San; SANTOS, Eleonora Campos da Motta. Profissão professor de balé: revisando referências e conceitos. Revista da FUNDARTE, Montenegro, p.202-220, ano 19, nํ37, Janeiro/Março.

Disponível em: http://.seer.fundarte.rs.gov.br/index.php/RevistadaFundarte/index> 30 de março de 2019. 


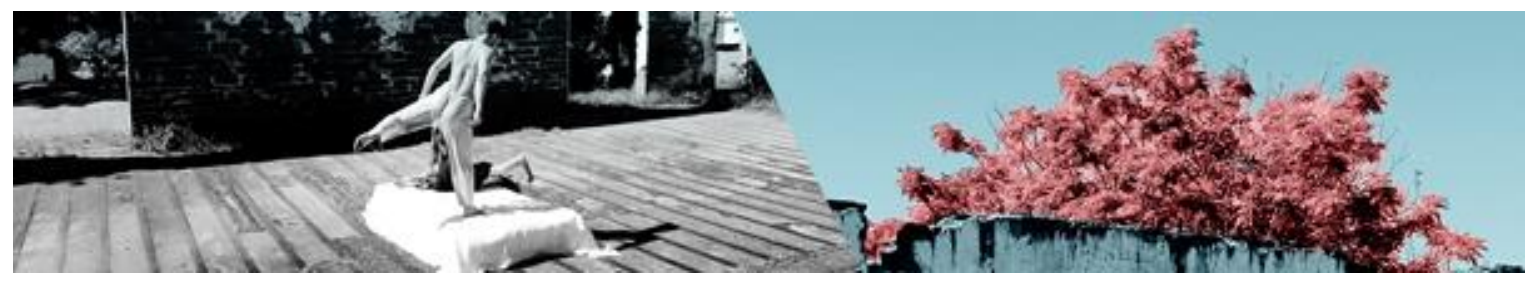

da mesma. Porém não passavam de danças sociais, as quais eram dançadas nos bailes realizados pela corte. Este autor nos ajuda a entender que foi a partir desse cenário e desse repertório de dança já existente que foi sendo concebido o formato dos "balés de corte" os quais partiram da ideia de bailes organizados com base em algum tipo de temática ou situação a ser exaltada (por exemplo: reviver momentos em que a França alcançou vitória em uma batalha importante).

O balé de corte nessa época estava desvinculado dos palcos. Sendo assim os bailarinos, as ações e os trechos de encenação dançados aconteciam no meio do público (BOURCIER, 2001). O objetivo do balé neste período estava muito vinculado a questões políticas, onde enaltecer a nobreza e os feitos da monarquia era uma das suas funções principais (SILVA, 2017).

Bourcier (2001) ainda ressalta que não existia profissionalismo no início do balé da corte. Os chamados "coreógrafos" eram na verdade os cortesãos, que em sua maioria eram da classe alta. Aos poucos foram, então, aparecendo alguns bailarinos profissionais, que tomaram o lugar dos cortesãos e em seguida os amadores não tiveram mais espaço no palco (BOURCIER, 2001). Os denominados amadores eram os cortesãos e até mesmo os próprios reis que eram amantes da dança.

Não havia uma grande distinção entre os profissionais e os amadores, só havia a exigência que atingissem um grande nível técnico durante as apresentações. Aos poucos esses amadores começaram a sair de cena dando espaço àqueles que passaram a se especializar na prática da dança, por isso, começaram a se destacar, consolidando um lugar de "profissionais".

É imprescindível pensar na importância do papel dos mestres e corégrafos, no que diz respeito à organização desses balés, e a forma que eles começaram a ser constituídos. Os mestres e coreógrafos também eram responsáveis em trabalhar nas entrées ${ }^{1}$ que tinham um grau de dificuldade maior (BOURCIER, 2001), ou seja, eles não desempenhavam apenas a função de ensinar os passos da dança, eles

MARTINS, Rebeca Pereira San; SANTOS, Eleonora Campos da Motta. Profissão professor de balé: revisando referências e conceitos. Revista da FUNDARTE, Montenegro, p.202-220, ano 19, ํㅡㄴ Janeiro/Março.

Disponível em: http://.seer.fundarte.rs.gov.br/index.php/RevistadaFundarte/index> 30 de março de 2019. 


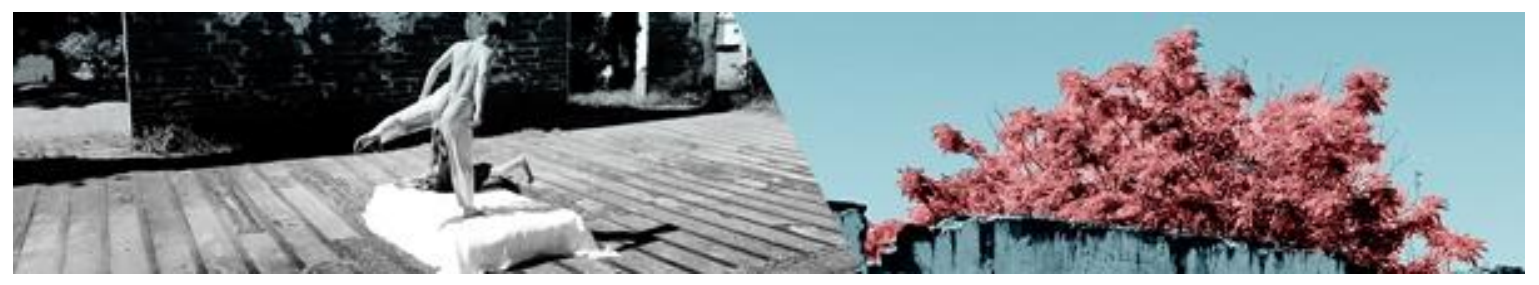

também acumulavam a função de organizar as estruturas espetaculares que compunham o balé de corte.

Após a morte de Luís XIII, quem assume o poder é seu filho Luís XIV. Durante seu reinado a arte e a cultura começam a traçar caminhos significativos alcançando seu auge (SILVA, 2017). Devido ao seu anseio de imobilizar o movimento de dança em regras, com o intuito primordial de beleza, em 1661, Luiz XIV cria a Academia Real de Dança.

O intuito dessa academia, estabelecida pelo rei, era conservar as movimentações e regras estabelecidas (BOURCIER, 2001). Utilizava-se, então, o ensino da dança para que houvesse disciplina na corte, pelo fato da dança ser considera prática fundamental da etiqueta, ou seja, todos os nobres teriam que dominá-la, assim como o rei (SILVA, 2017). Neste contexto a figura dos mestres de dança torna-se indispensável, pelo que podemos observar. Para que houvesse essa conservação de movimentação e aprimoramento, era necessário alguém que conduzisse esses nobres ao aprendizado, treinamento e aperfeiçoamento da prática desta dança codificada.

É importante citarmos o nome de Charles-Louis-Pierre de Beauchamps (1631 - 1705), grande dramaturgo e professor francês, da corte de Luis XIV, que teve um papel importantíssimo para a evolução da dança da época. Ele teve uma ação fundamental para elaboração e codificação da técnica clássica, sendo que foi ele quem definiu as cinco posições básicas dos pés (BOURCIER, 2001).

Naquele momento, de acordo com o mesmo autor, a regularidade, a beleza da forma e o virtuosismo são estabelecidos a partir de Beauchamps, para que a dança comece a seguir um novo padrão estético. Esse professor "trabalha a partir dos passos de dança de corte, atribuindo-lhes uma beleza formal, uma regra dentro da qual se fixa a via de sua evolução" (BOURCIER, 2001, p. 117). E Bourcier (2001, p. 116) ainda relata que: "Por um lado, a virtuosidade é a consequência natural da primazia da forma sobre o conteúdo".

MARTINS, Rebeca Pereira San; SANTOS, Eleonora Campos da Motta. Profissão professor de balé: revisando referências e conceitos. Revista da FUNDARTE, Montenegro, p.202-220, ano 19, ํㅡ 37, Janeiro/Março.

Disponível em: http://.seer.fundarte.rs.gov.br/index.php/RevistadaFundarte/index> 30 de março de 2019. 


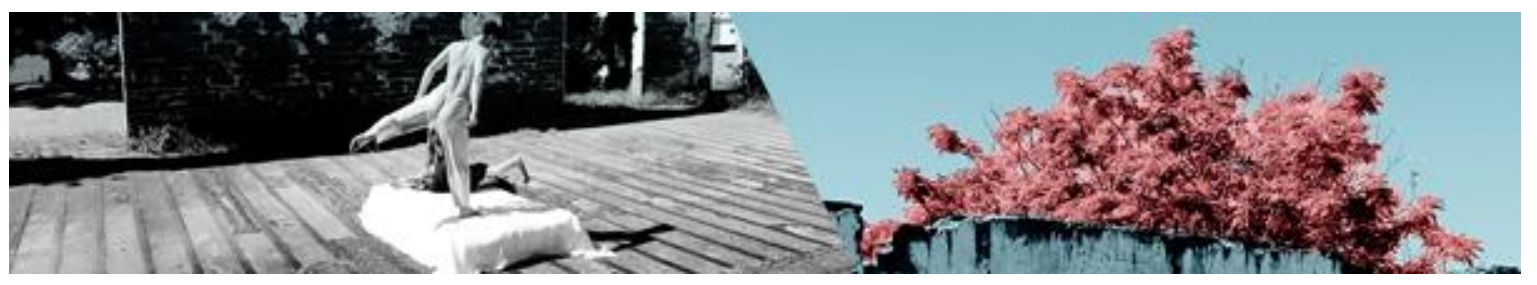

Como, na época de Luís XIV, o sistema adotado era o da beleza e o das formas, estruturado em um sistema de grande rigidez, a profissionalização da atuação em dança passa a exigir cada vez mais de quem atua no papel do professor.

Não podemos deixar de mencionar a Académia Royale de Danse, fundada em 1661 por Luís XIV, e que teve um papel importantíssimo no que diz respeito à contribuição do aperfeiçoamento da técnica e da consolidação de um modelo de figura de professor de dança, uma vez que tinha por intuito "[...] analisar e padronizar a dança, divulgando regras estabelecidas pelos seus integrantes (NUNES, 2016, p. 100)".

A escola era dirigida por Lany dos Gardel e a rotina lá exercida acarretou constante procura pelo virtuosismo (NUNES, 2016). Assim, escolas de dança legitimadas pela Academia Real a outras províncias francesas começam a surgir buscando tal exigência de qualidade técnica e artísticas dos seus alunos (SILVA, 2017). Passa a desenvolver-se fortemente, e de forma inevitável, o profissionalismo e a competição entre os próprios bailarinos, o que colabora com a gradual elevação do nível técnico de execução da dança.

Sobre as escritas em relação à atuação dos professores de dança produzida na época, Bourcier (2001, p. 153) aponta dois documentos publicados por Feuillet e Rameau, sendo que o último escreve sobre o professor de dança, mas sem detalhar seu conteúdo. Os dois autores dão indicações nas suas escritas apenas aos movimentos das pernas, deixando para trás a movimentação de braços, ombros e cabeça. Estes escritos foram muito importantes e permitiram que a técnica, a qual foi definida por escrito, chegasse até o público e fosse ensinada.

Novamente podemos perceber a figura do mestre e a saída dele da corte, pois no momento em que se instaura a Academia Real, esses mestres passam a atuar, também, nesse outro contexto. E os manuais passam a ser utilizados pelos mestres, que os utilizavam como base para os ensinamentos e progressão da técnica.

MARTINS, Rebeca Pereira San; SANTOS, Eleonora Campos da Motta. Profissão professor de balé: revisando referências e conceitos. Revista da FUNDARTE, Montenegro, p.202-220, ano 19, ํㅡㄴ Janeiro/Março.

Disponível em: http://.seer.fundarte.rs.gov.br/index.php/RevistadaFundarte/index> 30 de março de 2019. 


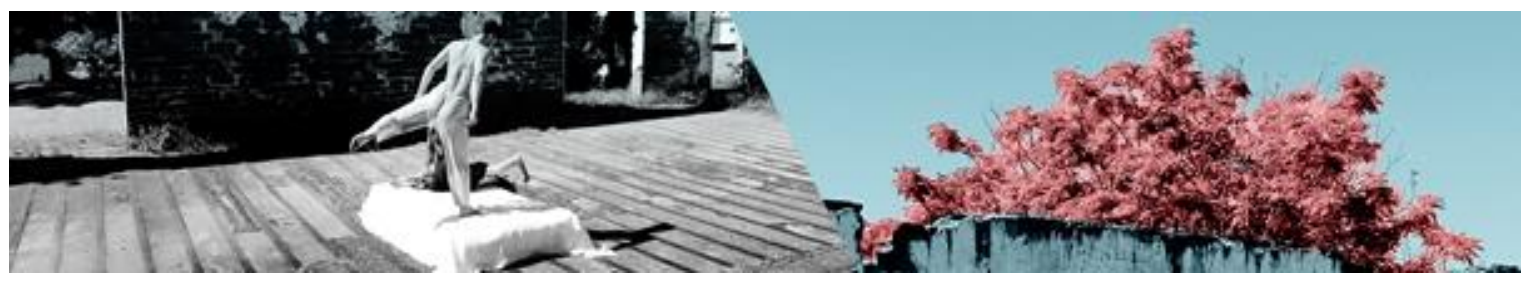

No final do século XVIII, Jean Georges Noverre (1727-1810), bailarino, mestre de dança e coreografo francês, trabalha no sentido de propor mudanças em relação ao que havia sendo realizado na estrutura cênica do balé da sua época.

Noverre foi uma grande influência no que diz respeito à constituição de uma nova dança (RENGEL; LANGENDONCK, 2006). Ele propôs o que foi denominado de "Balé de Ação" (MONTEIRO, 2006, p. 33), e uma das suas principais ideias era que o balé deveria narrar, de forma autônoma e fluída, com sentindo para quem assistisse, não sendo mais utilizado de forma tão fragmentada ou alegórica, como se apresentava nos Balés de Corte. Para ele, as organizações dos balés de corte não favoreciam o movimento coeso que a obra de dança deveria ter. Ele também acreditava que a naturalidade e a expressividade deveriam estar presentes na dança (BOURCIER, 2001, p. 170).

Noverre contestava a utilização das máscaras, pois acreditava que o rosto era fundamental para a interpretação. Quanto aos trajes, ele os considerava pesados e exagerados demais e que acabavam atrapalhando na movimentação e na graciosidade dos movimentos. Sobre a técnica de dança, ele acreditava que não possuía significado, ideias ou expressão (BOUCIER, 2001).

Todas essas considerações, dentre outras, sobre suas reflexões e proposições para a dança como espetáculo autônomo, Noverre registra em quinze cartas, deixando o que é considerado um dos principais legados teóricos sobre dança em uma época onde publicações sobre o tema não eram nada comuns.

Assim, Noverre possui um papel importante para a definição dos novos rumos que a dança clássica europeia começou a traçar a partir do século XVIII, tornandose um dos grandes mestres do balé daquela época (MONTEIRO, 2006, p. 23). Bourcier relata que:

Noverre propõe seu conjunto de reformas, que constituem um todo: o que é colocado em questão é a formação geral dos dançarinos e sua formação técnica, a formação dos professores de dança, a forma de trabalho dos compositores de balé. (BOURCIER, 2001, p. 173).

MARTINS, Rebeca Pereira San; SANTOS, Eleonora Campos da Motta. Profissão professor de balé: revisando referências e conceitos. Revista da FUNDARTE, Montenegro, p.202-220, ano 19, ํㅡㄴ Janeiro/Março.

Disponível em: http://.seer.fundarte.rs.gov.br/index.php/RevistadaFundarte/index> 30 de março de 2019. 


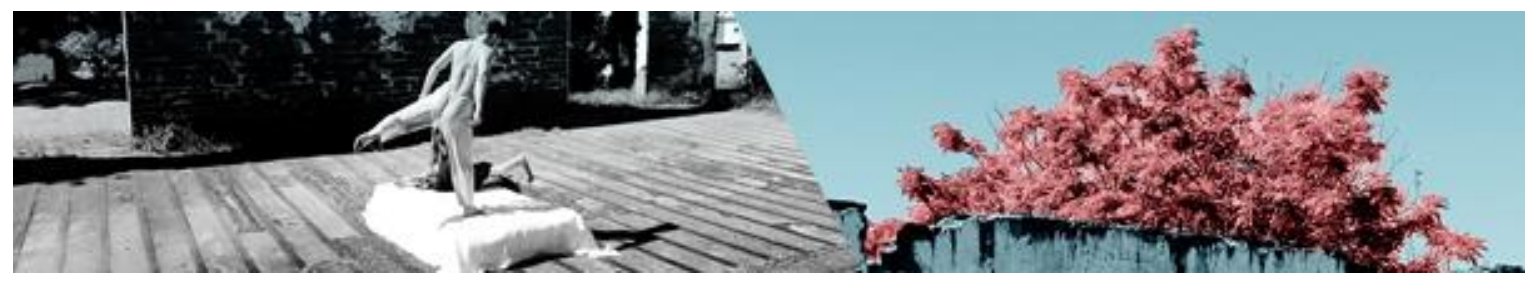

Consideramos importante destacar as reflexões de Noverre para pensar sobre como os mestres de dança atuavam naquela época, a fim de percebermos, mesmo que ainda de forma inicial, como o papel do professor se deu ao longo do tempo e como esse papel e a figura do professor se configuram a partir das reformas até os dias atuais.

\section{Ser professor de dança/balé: referências conceituais}

Ao escrever as Cartas Sobre a Dança, Noverre fala sobre o ser professor, ser um mestre de balé. Monteiro (2006) diz que Jean-Georges Noverre foi o "criador de uma obra teórica" a qual, em forma de cartas, evidência diversos pensamentos que dizem respeito ao balé clássico.

Como salientado anteriormente, as cartas foram organizadas em forma de livro com inúmeras edições e traduções em diversos países. Elas reúnem reflexões e posicionamentos sobre diversos aspectos da dança: desde a elaboração da cena e desenvolvimento da ideia do que seria o Balé de Ação, até a menção de aspectos e características que delineiam a atuação de um mestre de dança. Sendo este o ponto que interessa neste trabalho, importa mencionar aqui que não existe uma carta específica que aborde o tema do professor de dança.

Ao longo de muitas das cartas Noverre aponta críticas a posturas de mestres da época, ao mesmo tempo em que indica qual seria a postura adequada, na sua visão, para o bom desempenho da função. Noverre relata, na carta 1, que: "Um mestre de balé sem inteligência e sem gosto trata esse trecho de dança maquinalmente, e sem sentir-lhe o espírito, priva-o de seu efeito (NOVERRE apud MONTEIRO, 2006, p. 188) ". Esta colocação faz lembrarmos, imediatamente, dos professores de balé que realizam e trabalham voltando suas exigências para a reprodução minuciosa e uniforme dos movimentos, sem estimular a percepção dos sentidos e sensações relacionados à execução dos movimentos solicitados, fazendo com que o trabalho se torne algo frio e sem intensidade.

MARTINS, Rebeca Pereira San; SANTOS, Eleonora Campos da Motta. Profissão professor de balé: revisando referências e conceitos. Revista da FUNDARTE, Montenegro, p.202-220, ano 19, no 37, Janeiro/Março.

Disponível em: http://.seer.fundarte.rs.gov.br/index.php/RevistadaFundarte/index> 30 de março de 2019. 


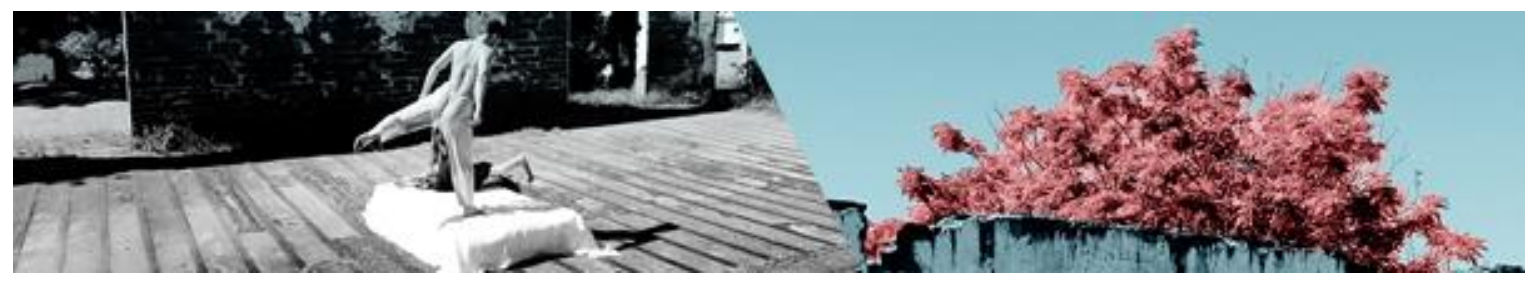

Outra questão a ser levantada é em relação a mestres que desejam que os bailarinos se modelem igualmente a eles. Em relação a isso, na carta 2, Noverre questiona esta postura considerando-a prejudicial ao desenvolvimento dos bailarinos, uma vez reprime os sentimentos e expressões individuais dos atuantes (NOVERRE, apud MONTEIRO, 2006).

Ele também relata a raridade em encontrar mestres de balé sensíveis, onde ainda menciona que: "são tão poucos os que são excelentes comediantes, os que possuem a arte de retratar os movimentos da alma por meio dos gestos." (NOVERRE apud MONTEIRO, 2006, p. 193). Esta colocação de Noverre nos faz refletir sobre o quão mecânico e artificial, muitas vezes, se torna o movimento, pois, ainda hoje, a exigência do balé e a busca pela perfeição faz com que os professores sejam extremistas e insensíveis, tanto em relação às individualidades do aluno, como também à intenção de sentimentos que determinado movimento provoca. Uma segunda reflexão que surge sobre este ponto é: não é somente no ensino do balé que verificamos "professores insensíveis". O que podemos perceber é que a estrutura da organização técnica do balé na relação com suas influências históricas favorece a prática docente baseada no ensino e reprodução mecânica de movimentos. Assim, 'como' o professor atua é o que define o caminho do processo de ensino - aprendizagem, e não necessariamente 'o que' ele está ensinando. Neste sentido, podemos pensar em aulas de diferentes danças que podem ser tão ou mais opressoras que uma aula de balé. Nesta direção, é possível perceber que estas observações de Noverre sobre a importância da sensibilidade do professor são referências que ainda marcam reflexões sobre quem escreve a respeito do perfil de quem ensina balé. O autor Wosien (2000), aborda que mesmo que o ensino do balé se caracterize por meio da imitação e inúmeras repetições, o professor precisa ter paciência, sensibilidade e estar atento às individualidades do aluno.

Voltando às colocações de Noverre (apud MONTEIRO 2006, p. 201), ele diz que: "um hábil mestre com um simples golpe de vista deve pressentir o efeito geral da máquina toda e jamais sacrificar o todo à parte". Ao que percebemos, Noverre

MARTINS, Rebeca Pereira San; SANTOS, Eleonora Campos da Motta. Profissão professor de balé: revisando referências e conceitos. Revista da FUNDARTE, Montenegro, p.202-220, ano 19, ํㅡㄴ Janeiro/Março.

Disponível em: http://.seer.fundarte.rs.gov.br/index.php/RevistadaFundarte/index> 30 de março de 2019. 


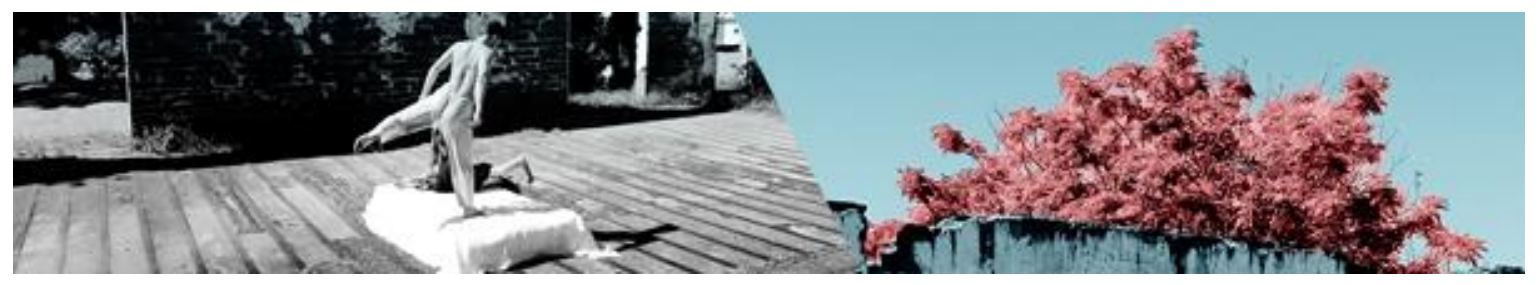

aponta que um mestre precisa estar atento a todos que estão ao seu redor e não obter um olhar fixado apenas em um ou mais integrante do grupo, pois se não, sua atuação se torna falha (MONTEIRO, 2006). O mestre de balé necessita apresentar aos bailarinos "uma ação, uma expressão e um caráter próprio", porém cada indivíduo deve traçar o seu caminho para alcançar o objetivo final (NOVERRE apud MONTEIRO, 2006).

Noverre também fala sobre a necessidade que vê de o professor buscar novos conhecimentos. Ele descreve, já no século XVIII, que, muitas vezes, a autoconfiança dos mestres de balé, a falta de desejo em avançar no seu trabalho, pressupõe que não há mais nada para além do que eles (mestres) já conhecem (apud MONTEIRO, 2006, p. 210). Tais indicações noverrianas reverberam em reflexões atuais sobre o ser professor e sobre o papel do professor de dança. Freire (2011) nos aponta que o educador necessita obter a percepção do não acabado e da importância de refletir criticamente sobre a sua prática, como também, estar envolvido com a sua ação docente, tendo em vista a necessidade do processo de aprendizagem continuada, em que está ensinando, mas também, aprendendo (FREIRE apud BORBA, 2013, p. 66). Neste mesmo sentindo Tardif (2014) nos aponta que os conhecimentos adquiridos na atuação servem de embasamento de práxis profissional, sendo tais experiências vivenciadas pelo docente o impulso para a construção de saberes individuas (TARDIF apud TAVARES, 2017, p. 38).

Sabemos que o ensino de dança hoje ainda está muito ligado a um modo tradicional de ensino que, muitas vezes, reproduz a figura do professor como detentor único do conhecimento. Contudo, no mesmo sentido do que já anunciava Noverre, percebemos indispensável rever o conjunto de valores e de princípios que se constituíram a partir de um pensamento ocidental de ensino (MARQUES, 2011). Referente ao ensino do balé clássico a autora Tassiana Resende relata que:

Esta arte, por ser fruto de uma formação tradicionalista em dança, faz com que professores repetissem as formas como aprenderam, ocorrendo na maioria das vezes, sem maiores reflexões no que tange a sensibilidade, possíveis implicações físicas e psicológicas do bailarino/aluno atuante nesta prática [...]. (RESENDE, 2010, p. 6).

MARTINS, Rebeca Pereira San; SANTOS, Eleonora Campos da Motta. Profissão professor de balé: revisando referências e conceitos. Revista da FUNDARTE, Montenegro, p.202-220, ano 19, no 37, Janeiro/Março.

Disponível em: http://.seer.fundarte.rs.gov.br/index.php/RevistadaFundarte/index> 30 de março de 2019. 


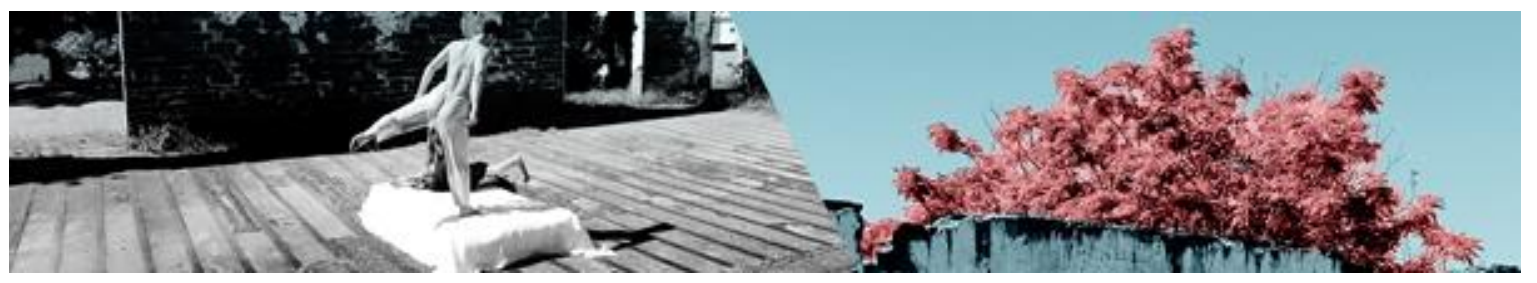

Entendemos que essa formatação de ensino faz com que, muitas vezes, haja um bloqueio no que diz respeito a uma formação que propicie experiências agradáveis, e que haja conscientização do próprio corpo, ou até mesmo que seja um lugar em que não tenha desrespeito e desvalorização do aluno (RESENDE, 2010). É neste momento, em que a sensibilidade do professor de dança/balé faz-se importante estar presente, para que sejam possíveis um ensino e um aprendizado compreensivos, colaborando para que a visão totalmente tradicional de ensino de balé clássico (e até mesmo de dança) na qual o aluno apenas reproduz a forma, algo já criticado por Noverre, comece a ser aos poucos repensada.

Nas cartas escritas por Noverre, ele ainda menciona a importância do estudo anatômico do corpo humano, pois considera que este conhecimento auxilie o mestre nos ensinamentos que serão feitos para aqueles que pretendem formar, o que pode ajudar a identificar os maus hábitos e as alterações que podem se opor ao desenvolvimento do aluno (NOVERRE apud MONTEIRO, 2006, p. 220). Com isso, se entrelaçam as questões abordadas acima, no que tange à necessidade de um professor que priorize o cuidado individual, levando em conta que cada um possui suas especificidades físicas e cognitivas, e que devem ser respeitadas durante seu aprendizado.

Indo ao encontro da ideia que Noverre traz, em relação ao cuidado com o corpo e a ressignificação do balé clássico, a autora Baldi (2016) trás um pouco desse contexto quando aborda a utilização de outras metodologias no ensino da dança. Neste sentido a autora menciona a importância do processo de (re)conhecimento: "o que significa ir além da anatomia, uma investigação de como se mover, do que está se movendo, etc (BALDI, 2016, p. 263)". Para que este processo de (re)conhecimento aconteça parece ser preciso que o professor se desprenda do ensino tradicional e esteja disposto a mediar este processo de percepção individual de cada aluno. Baldi (2016) ainda traz em seu texto que:

MARTINS, Rebeca Pereira San; SANTOS, Eleonora Campos da Motta. Profissão professor de balé: revisando referências e conceitos. Revista da FUNDARTE, Montenegro, p.202-220, ano 19, ํㅡㄴ Janeiro/Março.

Disponível em: http://.seer.fundarte.rs.gov.br/index.php/RevistadaFundarte/index> 30 de março de 2019. 


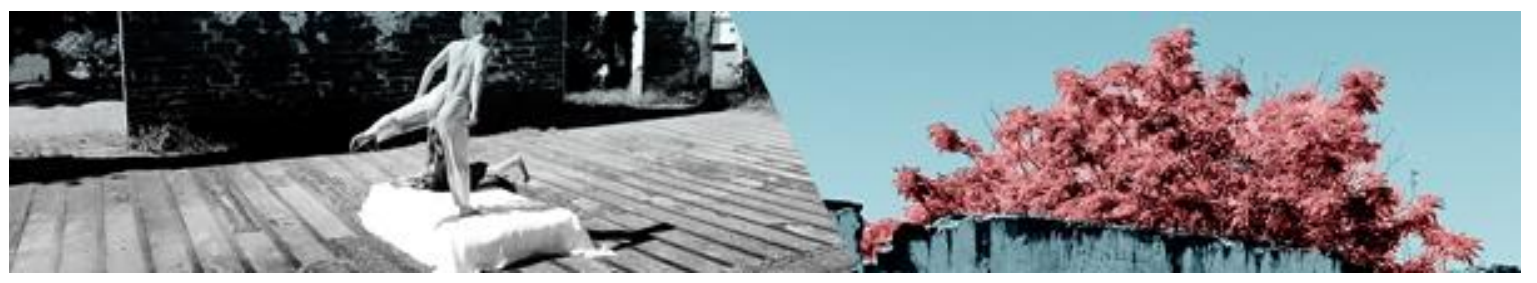

Esta elaboração implica aproximar-se de tal objeto ou conteúdo com finalidade de aprendê-lo; não se trata de uma aproximação vazia, a partir do nada, mas a partir das experiências, interesses e conhecimentos prévios que, presumivelmente, possam dar conta da novidade. (BALDI apud SOLE்; COLL, 2009).

Trazendo essa ideia para o ensino do balé é possível pensarmos em um processo que não se dê, somente, partir de uma cópia e repetição de movimentos, mas que tome como base, também, as experiências corporais individuais e a realidade de cada discente, para que este ensino e esta aproximação com o conteúdo que está sendo ensinado não se torne vazia.

Marques (2012) ainda menciona que, para que haja uma compreensão crítica, consciente e dotada de sentidos, é preciso que os discentes se apropriem dos elementos que determinada linguagem de dança traz consigo. No entanto, para que o processo ocorra é necessário que haja, como já mencionado, uma preocupação com os modos de ensino e aprendizagem que está sendo abordada, para que se extrapole o conceito de reprodução estética na direção da prática de repetição produtiva.

Após reunir as considerações sobre as ideias do que é ser professor de dança, partindo das concepções de Noverre, foi possível percebermos e destacarmos alguns conceitos que o mestre percebia e idealizava como uma postura adequada para um professor de dança.

Com base no que foi mencionado ao longo deste capítulo e nas leituras realizadas sobre Noverre, pode-se destacar algumas das características que ele acreditava ser importante um mestre obter: prezar a expressividade e o sentimento na dança; obter um conhecimento anatômico; oportunizar aos alunos expressão e característica própria; possuir um olhar sensível; ter certa fruição e conhecimento em outras artes. Por conseguinte, também podemos destacar algumas das características de um professor de dança que Noverre desvaloriza, sendo elas: conduzir a dança maquinalmente; visar que os bailarinos se moldem como eles; acreditar já serem os detentores do saber.

MARTINS, Rebeca Pereira San; SANTOS, Eleonora Campos da Motta. Profissão professor de balé: revisando referências e conceitos. Revista da FUNDARTE, Montenegro, p.202-220, ano 19, ํㅡㄴ Janeiro/Março.

Disponível em: http://.seer.fundarte.rs.gov.br/index.php/RevistadaFundarte/index> 30 de março de 2019. 


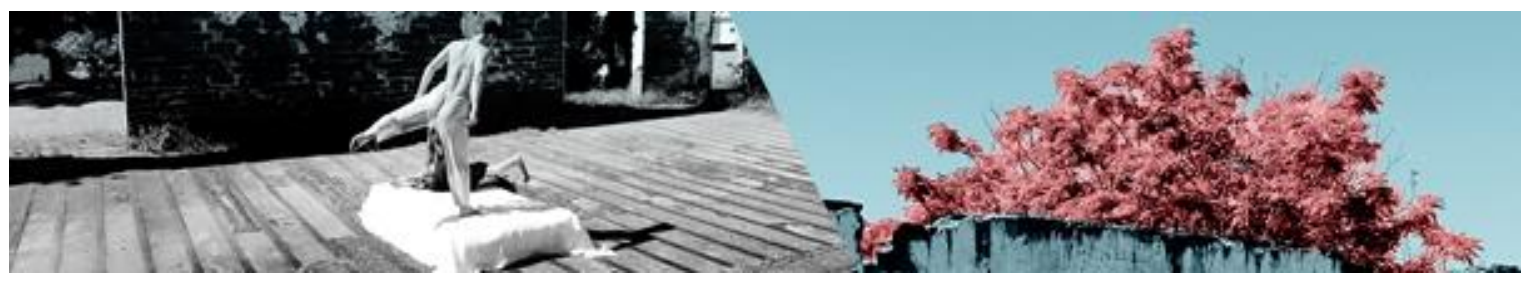

\section{Considerações Finais}

É possível perceber que algumas considerações Noverrianas ainda repercutem e reverberam no que diz respeito à forma de pensar em relação à atuação do docente na dança.

Neste sentido, o autor Wosien (2000) fala da importância do professor obter uma sensibilidade que o torne capaz de perceber cada aluno, e estar atento as suas individualidades. Os autores Baldi (2016) e Marques (2012) trazem algumas questões referentes à importância do professor estimular o autoconhecimento. Baldi traz o conceito do (re)conhecimento, como algo que possibilita ao discente obter uma percepção individual de si e daquilo que ele está se propondo a executar. Neste mesmo sentido Marques (2012), reitera que é fundamental que o aluno tenha uma apropriação do que está sendo ensinado para que seja possível haver uma compressão crítica e consciente dos movimentos que realiza. Podemos fazer uma ligação do pensamento desses dois autores com o que Noverre dizia quando criticava a forma como os mestres conduziam a dança de uma forma mecânica.

Já Freire (2011) e Tardif (2014) abordam algumas questões referentes à construção dos saberes docentes ${ }^{2}$. Freire menciona que o professor necessita ter uma percepção do "não acabado" e estar sempre refletindo sobre sua prática e em um processo de formação continuada. Para Tardif os conhecimentos que são adquiridos na atuação docente e as experiências vivenciadas neste contexto possibilitam um impulso para a construção de novos saberes. Nesse sentido, estes dois autores, assim como Noverre, acreditam que o professor precisa estar em constante processo de aprendizagem, se reinventando e buscando novos conhecimentos.

Ao longo deste trabalho conseguimos refletir sobre os diferentes significados do balé clássico, no sentindo de compreendermos como essa técnica se consolidou e os caminhos que foram sendo delineados pelos mestres que foram surgindo na corte europeia. As percepções que foram sendo adquiridas sobre o professor de

MARTINS, Rebeca Pereira San; SANTOS, Eleonora Campos da Motta. Profissão professor de balé: revisando referências e conceitos. Revista da FUNDARTE, Montenegro, p.202-220, ano 19, ํㅡㄴ Janeiro/Março.

Disponível em: http://.seer.fundarte.rs.gov.br/index.php/RevistadaFundarte/index> 30 de março de 2019. 


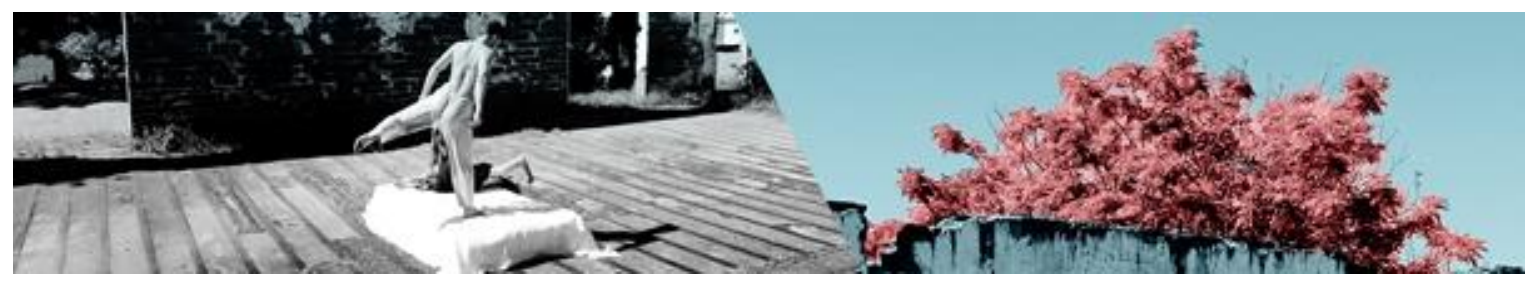

dança/balé começaram a ser ressignificadas a partir do momento em que as reflexões acerca deste assunto começaram a ser constituídas. Percebemos o quanto a característica do professor de dança ainda está ligada à ideia construída no contexto das cortes nobres europeias dos séculos XVI, XVII e XVIII.

Fica evidente que as mudanças em relação às metodologias no ensino do balé têm acontecido ao longo do tempo, e que novas maneiras de ensinar a técnica do balé clássico vêm sendo desenvolvidas por diversos professores. A literatura mostra que a figura do professor de dança vem se modificando, mas é notório que muitas das práticas e pensamentos, que já perfaziam a atuação dos mestres de dança na época de Noverre, ainda reverberam nas atuações dos professores de hoje.

Este estudo inicial, sobre fontes e conceitos em torno da constituição da figura do professor de dança, permitiu perceber o quanto há ainda a ser explorado, especialmente na direção de ampliarmos a revisão de fontes que possam apontar registros de modos e lógicas de atuação deste profissional.

\section{Referências:}

BALDI, Neila. Educação somática e construtivismo: revendo a pedagogia da dança. Competência: revista ouvirOUver, Uberlândia, v. 12, n. 2, p. 256-269, 2016.

BORBA, Mônica Corrêa. Profissão: Professor de Dança! A trajetória de formação de uma professora de Balé Clássico na cidade de Pelotas. Pelotas, 2013. $125 f$.

BOURCIER, Paul. História da dança no Ocidente. São Paulo: Martins Fontes, 2001.

BOURCIER, Paul. História da dança no Ocidente. São Paulo: Martins Fontes, 2006.

FREIRE, Ana Vitoria. Angel Vianna: Uma biografia da dança contemporânea. Brasil, 2005.

FREIRE, Paulo. Pedagogia da Autonomia: saberes necessários à prática educativa. São Paulo: Paz e Terra, 2011.

MARTINS, Rebeca Pereira San; SANTOS, Eleonora Campos da Motta. Profissão professor de balé: revisando referências e conceitos. Revista da FUNDARTE, Montenegro, p.202-220, ano 19, ํㅡㄴ Janeiro/Março.

Disponível em: http://.seer.fundarte.rs.gov.br/index.php/RevistadaFundarte/index> 30 de março de 2019. 


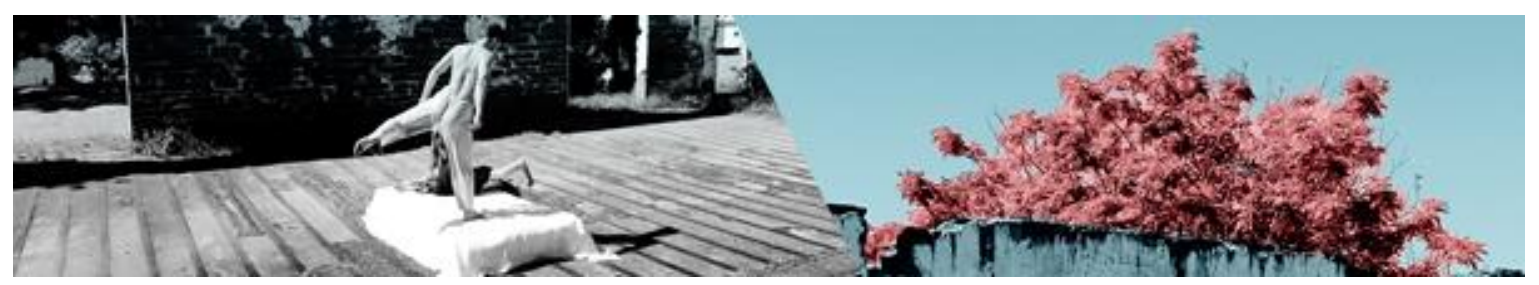

MARQUES, Isabel. Dança na escola: Arte e ensino. 2012. Disponível em: $<$ http://www.ficms.com.br/web/biblioteca/Dan\%E7a\%20na\%20Escola.pdf >. Acesso em: 15 de janeiro de 2018.

MARQUES, Isabel. Notas sobre o corpo e o ensino de dança. Competência: Caderno pedagógico, Lajeado, v. 8, n. 1, p. 31-36, 2011.

MONTEIRO, Mariana. Noverre: Cartas sobre a dança. São Paulo: Editora Universidade de São Paulo: Fapesp, 2006. p. 21-245.

MARTIN, Bauer; GASKELL, George. Pesquisa qualitativa com texto: imagem e som. ed. 10, Petrópolis, RJ: Vozes, 2012.

NÓVOA, António; FINGER, Matthias (Org.). O método (auto)biográfico e a formação. Natal, RN: EDUFRN; São Paulo: Paulus, 2010.

NUNES, Bruno. O fascínio das danças de corte. Curitiba: Appris, 2016.

PORTINARI, Maribel. História da dança. Rio de Janeiro: Nova Fronteira, 1989.

PORTINARI, Maribel. Eugenia Feodorova: a dança da alma russa. Editora: Ministério da Cultura, FUNARTE, 2001.

RESENDE, Tassiana. Outros olhares para o ensino do ballet clássico. Goiânia, 2010. 25.p.

SAMPAIO, Flavio. Ballet Essencial. Rio de Janeiro: SPRINT, 3ae edição, 2001.

SILVA, Daniela. Corpo - Escrita no balé: Para repensar o corpo doce da bailarina da caixinha de música em uma pesquisa em educação e arte. Tese (Doutorado em educação) - Universidade Federal de San Maria, San Maria, 2017.

TAVARES, Érika. Professores de Danças urbanas da Cidade de Pelotas (20022016): trajetórias e entendimentos sobre formação docente superior. 2017.

TARDIF, Maurice. Saberes docentes e formação profissional. 17ª Ed. Petrópolis, RJ: Vozes, 2014.

MARTINS, Rebeca Pereira San; SANTOS, Eleonora Campos da Motta. Profissão professor de balé: revisando referências e conceitos. Revista da FUNDARTE, Montenegro, p.202-220, ano 19, ํo 37, Janeiro/Março.

Disponível em: http://.seer.fundarte.rs.gov.br/index.php/RevistadaFundarte/index> 30 de março de 2019. 


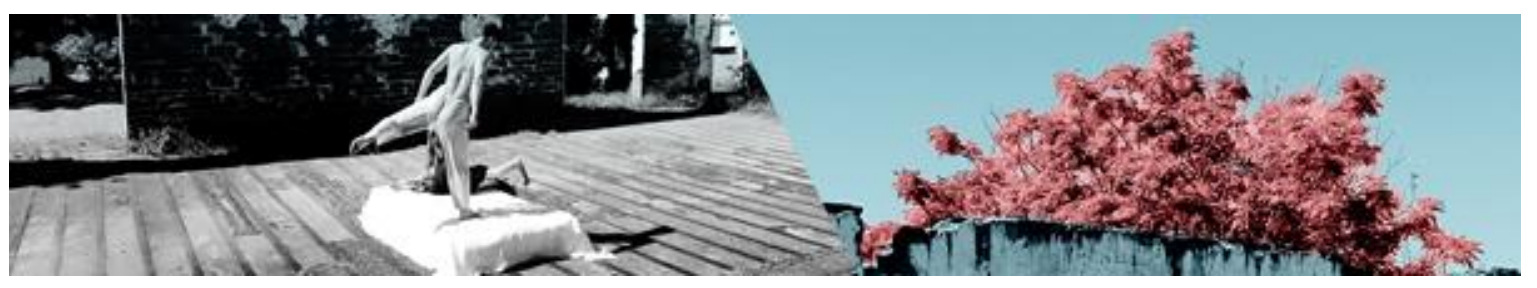

TARDIF, Maurice. Saberes docentes e formação profissional. 4" Ed. Rio de Janeiro: Vozes,

2002.

WOSIEN, Bernhard. Dança: Um caminho para a totalidade. São Paulo: Triom, 2000.

Notas:

1. Espécie de trechos de encenação dançados, ligados à temática ou contexto narrado naquele baile, com momentos específicos para acontecerem durante as festas. Estes momentos exigiam entradas e saídas articuladas com o contexto do baile, bem como música, figurino e ambientação específica. Os mestres acumulavam a organização da dança articulado a esse conjunto de elementos. Para melhor compreender o contexto dos balés de cortes, sugerimos a leitura de Monteiro (2006).

2. Os saberes docentes estão relacionados com a identidade particular, com as experiências de vida, com a história profissional de cada individuo, com sua relação com os alunos e com os demais sujeitos presentes no loca de ensino (TARDIF, 2002).

MARTINS, Rebeca Pereira San; SANTOS, Eleonora Campos da Motta. Profissão professor de balé: revisando referências e conceitos. Revista da FUNDARTE, Montenegro, p.202-220, ano 19, ํo 37, Janeiro/Março.

Disponível em: http://.seer.fundarte.rs.gov.br/index.php/RevistadaFundarte/index> 30 de março de 2019. 